\title{
RELEVANSI METODE PEMBENTUKAN PENDIDIKAN KARAKTER DALAM KITAB TA'LIM AL-MUTA'ALLIM TERHADAP DUNIA PENDIDIKAN MODERN
}

\author{
Muhammad Zamhari \& Ulfa Masamah \\ UIN Sunan Kalijaga, Yogyakarta, Indonesia \\ muhammad.zamhari@uin-suka.ac.id
}

\begin{abstract}
Abstrak
Pendidikan karakter dalam kitab Ta'lim al-Mutaallim oleh Burhanuddin al- Zarnuji adalah internalisasi nilai-nilai adab ke dalam pribadi siswa. Internalisasi ini merupakan proses pembangunan jiwa yang berasaskan konsep keimanan. Gagalnya sebuah pendidikan karakter yang terjadi selama ini disebabkan karena pendidikan karakter yang diajarkan minus nilai keimanan dan konsep adab. Sehingga, proses pembangunan karakter tersendat bahkan hilang sama sekali. Untuk membentuk penuntut ilmu yang berkarakter dan beradab, maka pendidikan Islam harus mengarahkan target pendidikan pada pembangunan individu yang memahamai tentang kedudukannya, baik kedudukan dihadapan Tuhan, masyarakat, dan dirinya sendiri. Kitab Ta'lim al-Muta'allim merumuskan tiga metode penting dalam pembentukan karakter yang mencakup adab dhahir dan batin, meliputi metode ilqa' al-nasihah (pemberian nasehat) dan kasih sayang; metode Mudzakarah, Munadharah, dan Mutharahah; Metode pembentukan mental jiwa. Ketiga metode tersebut perlu untuk diuji relevansinya dengan kondisi pendidikan saat ini. Penelitian yang bersifat studi kepustakaan ini menunjukkan bahwa tiga metode tersebut masih relevan untuk digunakan dalam pendidikan saat ini.
\end{abstract}

Kata kunci: pendidikan karakter, metode, adab, batin 


\section{Abstract}

THE RELEVANCE OF CHARACTER EDUCATION ESTABLISHMENT METHOD IN TA'LIM MUTA'ALIM BOOK TOWARDS MODERN EDUCATION WORLD. Character education in ta'limul-muta'aalim (the method of learning) by Burhanuddin alZarnuji is an internalization process of character and ethic into a student. This process covers mental development based on the faith concept. The failure of character education is caused by the lack of the faith and ethic. Consequently, the character development is obstructed and even it is failed. To create character and ethic learners, Islamic education should point the aim of education on development of individual who knows his position to the God, society, and themselves. Ta'limul-muta'allim formulated three important methods in character development covering body and soul, i.e., ilqa' al-nasihah (advisory) and affection method; Mudzakarah, Munadharah, and Mutharahah method; and mental and spiritual development method. These three methods are needed to check the relevance to current education. This library research showed that these method are still relevant to be used in nowadays education.

Keywords: character education, methods, adab (ethic), spiritual

\section{A. Pendahuluan}

Pendidikan merupakan proses pembentukan kemampuan dasar fundamental yang menyangkut daya pikir (intelektual) maupun daya rasa (emosi) individu (Jalaluddin dan Idi, 2010: 21). Dipandang sebagai bagian integral dari proses menata dan mengarahkan individu menjadi lebih baik, maka pendidikan menjadi satu-satunya jaminan kehidupan umat manusia menjadi lebih berakhlak (bermoral) (Wena, 2011: 17). Akan tetapi, dalam perjalanannya pendidikan terus mengalami perubahan dan perkembangan dengan karya dan potensi yang dimiliki setiap level generasi. Hal inilah yang menjadikan pendidikan sebagai suatu proses sistemik yang masuk ke berbagai ruang dan dimensi permasalahan yang dihadapi manusia.

Berbagai permasalahan yang terjadi pada Bangsa Indonesia saat ini adalah krisis moral dan karakter manusianya yang merambah pada hampir semua segmen kehidupan dan lapisan masyarakat, tak terkecuali pada segmen pendidikan. Keadaan pendidikan akhir-akhir ini semakin memprihatinkan 
dan meresahkan masyarakat sehingga membutuhkan dengan segera solusi yang solutif atas kondisi yang ada.Krisis yang paling menonjol adalah krisis pendidikan moral/akhlak atau dalam pengertian sekarang adalah krisis karakter. Erie Sudewo melalui karyanya Best Practice Character Building (Salahuddin dan Alkrienciehie, 2013: 31), bahwa kemelut Indonesia yang semakin carut marut ini karena ketiadaan karakter. Kenihilan karakter akan menjadi masalah besar dan menjadikan bangsa tersebut ibarat layangan putus dan limbung diterpa angin, sehingga akan menghilangkan martabat sebagai suatu negara.

Realitas yang ada memperlihatkan rendahnya nilai karakter bangsa semakin membuat dekadensi moral generasi dan segera membutuhkan solusi. Salah satu permasalahan yang semakin marak terjadi adalah kasus para guru yang dipenjarakan atau dilaporkan ke pihak polisi oleh orang tua murid yang tidak terima cara guru dalam mendidik anaknya. Guru pun semakin tertekan karena kenakalan remaja terus meningkat sementara wewenang guru dalam mendidik justru dibatasi dengan adanya UU Perlindungan anak (UU No. 23 Tahun 2002 tentang Perlindungan Anak). Hal ini berdampak pada hilangnya rasa sopan, hormat dan segan terhadap guru yang telah mencerdaskan generasi umat manusia. Wajah pendidikan semakin memprihatinkan dengan banyaknya penyimpangan akhlak seperti masalah narkoba, hubungan seksual bebas/pranikah, aborsi, perkelahian, tawuran dan kekerasan. Hal ini diperparah dengan akibat dari kenakalan remaja tersebut banyaknya korban yang luka-luka, bahkan jiwa pun melayang.

Sisi lain menunjukkan bahwa dunia pendidikan terutama dalam hal hubungan antara guru dan siswa masih menganut gaya feodal. Hal ini ditunjukkan dengan adanya guru-guru yang membatasi diri terhadap siswa karena kekhawatiran akan turunnya wibawa dihadapan para siswa. Seharusnya, kewibawaan guru tidak ditentukan oleh kedekatannya dengan siswa, akan tetapi lebih ditentukan oleh kepandaiannya menempatkan diri dalam fungsinya sebagai pendidik. Dengan kata lain, bila dalam melaksanakan tugasnya guru bersikap adil dan bijaksana dalam segala aspek yang berhubungan dengan proses pembelajaran, maka anak didik akan tetap hormat dan segan kepada guru tersebut. 
Fenomena inilah yang membuat dunia pendidikan di Indonesia tidak mampu menahan kemerosoton karakter yang terjadi. Ini merupakan akibat dari titik berat pendidikan yang masih lebih banyak pada masalah kognitif (Zainuddin, 2009: 263-264).Aspek lain seperti afektif (attitude) nampaknya masih menjadi pelengkap. Dengan kata lain, pembelajaran di kelas yang mengarah kepada pembentukan karakter siswa hampir dikatakan belum pernah dilakukan secara sistematis dan terencana sebagaimana dengan sistem nilai (value system). Bahkan jika dilihat dari sudut global, munculnya berbagai permasalahan yang mendera bangsa Indonesia sebagai akibat rendahnya moral dan karakter para pelaku kebijakan yang juga diikuti oleh rendahnya etos kerja masyarakat. Salah satu solusi yang tepat adalah penerapan pendidikan yang berlandaskan karakter yang tidak hanya sekedar wacana belaka. Pada prinsipnya secara umum pendidikan karakter tidak dapat tercipta dengan cara praktis atau cepat, namun harus melewati suatu proses yang panjang, cermat dan sistematis.

Perlunya pendidikan dengan prioritas karakter ataupun moral sebagaimana dijelaskan AllahSWT dalam QS. AlQalam:4,"Dan sesungguhnya kamu benar-benar berbudi pekerti yang agung". Ayat di atas menjadi kunci betapa Allah SWT sangat menekankan kepada umat manusia untuk memiliki akhlak atau karakter dalam berbagai aspek kehidupan, hal ini terbukti dengan diutusnya Nabi Muhammad SAW untuk menyempurnakan akhlak manusia, dan dalam praktik kehidupan beliau dikenal sebagai berakhlak yang agung dan pantas untuk diteladani. Menurut Sukro Muhab (Salahudin, 2009: 46) keteladanan dan akhlak Nabi Muhammad SAW ini sampai menggugah Mahatma Gandi dengan menyatakan: "Saya lebih dari yakin bukanlah pedang yang memberikan kesadaran pada Islam pada masanya, Tapi, ia datang dari kesederhanaan, kebersahajaan, kehati-hatian Muhammad serta pengabdian luar biasa kepada teman dan pengikutnya, tekadnya, keberaniannya serta keyakinannya pada Tuhan dan tugasnya”.

Berdasarkan fenomena pendidikan akhlak atau karakter di atas, banyak para ahli yang membahas tentang pendidikan 
akhlak atau pendidikan karakter, diantaranya Burhanuddin alZarnuji. Dengan berbagai kitab yang dikarang oleh para ahli tersebut sehingga menunjukkan akan pentingnya pendidikan karakter yang merupakan tujuan puncak dari pendidikan dengan membentuk karakter positif dalam perilaku anak didik. Dan karakter positif itu sendiri tiada lain adalah penjelmaan sifat-sifat mulia Tuhan dalam kehidupan manusia. Pendidikan karakter menurut Islam dalam kitab Ta'lim al-Muta'allim adalah internalisasi nilai-nilai adab ke dalam pribadi siswa. Internalisasi ini merupakan proses pembangunan jiwa yang berasaskan konsep keimanan. Gagalnya sebuah pendidikan karakter yang terjadi selama ini disebabkan karena karakter yang diajarkan minus nilai keimanan dan konsep adab. Sehingga, proses pembangunan karakter tersendat bahkan hilang sama sekali. Untuk membentuk penuntut ilmu yang berkarakter dan beradab, maka pendidikan Islam harus mengarahkan target pendidikan pada pembangunan individu yang memahami tentang kedudukannya, baik kedudukan dihadapan Tuhan, masyarakat, dan dirinya sendiri.

Dari latar belakang di atas, penulis memfokuskan pembahasan kajian ini dengan beberapa rumusan masalah sebagai berikut: a) Bagaimana metode pembentukan pendidikan karakter dalam kitab Ta'lim al Muta'allim?, b) Bagaimana relevansi metode pembentukan pendidikan karakter tersebut dalam dunia pendidikan modern?

Untuk menjawab permasalahan diatas, penelitian ini menggunakan pendekatan studi kepustakaan. Subjek dalam penelitian ini adalah tiga metode pengajaran pendidikan karakter yang termuat dalam kitab Ta'lim al Mutáallim karya Syekh al-Zarnuji. Kitab Ta'lim al Muta'allim merupakan kitab yang membahas tentang tata cara dalam belajar atau mencari ilmu. Kitab ini terdiri dari 13 pasal. Penelitian ini bersifat studi kepustakaan (library research). Menurut sumbernya, data penelitian ini meliputi data primer dan data sekunder. Pengumpulan data dilakukan dengan cara membaca dan menelaah literatur yang ada. Tipe yang digunakan untuk analisis data adalah tipe deskriptif analitik, yaitu dengan cara mengumpulkan data kemudian data tersebut 
disusun, dijelaskan, dianalisis, kemudian diambil kesimpulan (Hadi, 1989:42).

\section{B. Pembahasan}

Akhlak merujuk kepada tugas dan tanggung jawab selain syariah dan ajaran Islam secara umum. Sedangkan term adab merujuk kepada sikap yang dihubungkan dengan tingkah laku yang baik. Keteladanan merujuk kepada kualitas karakter yang ditampilkan muslim baik yang mengikuti keteladanan Nabi Muhammad SAW. Ketiga nilai inilah yang menjadi pilar pendidikan karakter dalam Islam. Sebagai usaha yang identik dengan ajaran agama, pendidikan karakter dalam Islam memiliki keunikan dan perbedaan dengan pendidikan karakter di dunia Barat. Perbedaan-perbedaan tersebut mencakup penekanan terhadap prinsip-prinsip agama yang abadi, aturan dan hukum dalam memperkuat moralitas, perbedaan pemahaman tentang kebenaran, penolakan terhadap otonomi moral sebagai tujuan pendidikan moral, dan penekanan pahala di akhirat sebagai motivasi perilaku bermoral. Inti dari perbedaan-perbedaan ini adalah keberadaan wahyu Illahi sebagai sumber dan rambu-rambu pendidikan karakter dalam Islam. Dengan demikian, pendidikan karakter dalam Islam lebih sering dilakukan secara doktriner dan dogmatis, tidak secara demokratis dan logis.

Syeikh Burhanuddin al-Zarnuji penulis kitab Ta'lim alMuta'allim menekankan aspek nilai adab, baik adab batiniyah maupun adab lahiriyah dalam pembelajaran. Kitab ini mengajarkan bahwasanya pendidikan tidak hanya transfer ilmu pengetahuan dan keterampilan (skill), akan tetapi yang paling penting adalah transfer nilai adab. Dengan demikian pendidikan karakter haruslah mendasarkan pada nilai religius, bukan justru anti religius. Pemahaman umum yang diyakini kebanyakan pendidik, pendidikan karakter adalah pendidikan budi pekerti yang melibatkan aspek pengetahuan, perasaan, dan tindakan, dan mengesampingkan nilai religious. Definisi pendidikan ini masih menyisakan problem.

Syeikh al-Zarnuji dalam kitab Ta'lim al-Muta'allim merumuskan beberapa metode penting dalam pembentukan 
karakter yang mencakup adab lahir dan batin. Adapun metode tersebut adalah 1) metode ilqa' al-nasihah (pemberian nasehat) dan kasih sayang; 2) metode Mudzakarah, Munadharah, dan Mutharahah;3) Metode pembentukan mental jiwa.

\section{Metode Kasih Sayang dan Ilqa' al-Nasihah (Pemberian Nasehat)}

Syeikh al-Zarnuji menjelaskan bahwa:

$$
\begin{aligned}
& \text { ينبنغى أن يكون صـاحب العلهم مشـفقا نـاصسحا غير حاسد، } \\
& \text { فالحسد يضرولا ينفع. وكان أستاذنا شيخ الإسلام برهان الدين } \\
& \text { رحمه الله يقول: قالوا إن ابن المعلم يكون عالما لأن المعلم }
\end{aligned}
$$

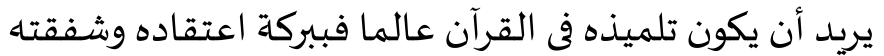

$$
\begin{aligned}
& \text { يكون ابنه عالما }
\end{aligned}
$$

"Orang alim hendaknya memiliki rasa kasih sayang, mau memberi nasehat serta jangan berbuat dengki. Dengki tidak akan memberikan manfaat, justru membahayakan diri sendiri. Guru kita Syaikhul Islam Burhanuddin ra. Berkata: Banyak ulama yang berkata: "Putra sang guru dapat menjadi alim, karena sang guru itu selalu berkehendak agar muridnya kelak menjadi ulama ahli Alquran. Kemudian atas berkah i'tikad bagus dan kasih sayangnya itulah putranya menjadi alim."

Berdasarkan pada penjelasan di atas, kasih sayang merupakan merupakan salah satu pembelajaran yang tepat diterapkan untuk membentuk karakter peserta didik. Mayor (1996) menyatakan bahwa hanya ada satu pedagogi, yaitu pedagogi kasih sayang. Hal ini dikarenakan kasih sayang merupakan dasar pendidikan (Cetron, 1996). Apabila pendidik sudah kehilangan kasih sayangnya pada peserta didik, hal ini menandakan pendidikan mulai kehilangan jati dirinya. Oleh karena itu, bagaimanapun canggihnya komputer dalam membantu kegiatan pembelajaran, tetap tidak akan dapat menggantikan peran dan fungsi guru. Dengan demikian proses pembelajaran akan dapat mencapai tujuan secara optimal bila dilandasi oleh kasih sayang guru dalam setiap tindakan pembelajaran. 
Nabi Muhammad SAW telah memberikan keteladanan terkait dengan pemberian kasih sayang dan nasehat dalam pembelajaran sebagaimana dikisahkan bagaimana Rasulullah (HR Muslim, Kitab al Hudud: 3208) memperlakukan bayi dengan kasih sayang meskipun anak hasil perzinaan. Diantara bukti yang menunjukkan belas kasihan Nabi kepada bayi dan keinginannya yang sangat agar bayi tumbuh menjadi besar dari air susu ibu. Ketika datang kepada Nabi SAW seorang wanita dari Bani Ghamidiyah yang mengemukakan pengakuannya di hadapan beliau bahwa dirinya telah mengandung dari hasil perbuatan zina, maka Nabi SAW bersabda kepadanya: "Pulanglah kamu sampai kamu melahirkan!" setelah bersalin ia datang lagi seraya menggendong bayinya dan berkata: "Wahai Nabi Allah, bayi ini telah saya lahirkan. "Akan tetapi, Nabi SAW bersabda kepadanya: "Pulanglah kamu: susuilah dia sampai kamu menyapihnya." Setelah wanita itu menyapihnya, ia datang dengan membawa bayinya yang saat itu dalam keadaan memegang sepotong roti ditangannya, lalu ia berkata: "Wahai Nabi Allah, bayi ini telah saya sapih dan kini dia telah dapat memakan makanan." Nabi SAW pun memerintahkan agar bayi itu diserahkan kepada salah seorang lelaki dari kaum muslimin dan memerintahkan agar dibuatkan galian sebatas dada untuk menanam tubuh wanita itu, kemudian memerintahkan kepada orang-orang untuk merajamnya dan merekapun segera merajamnya (Rahman, 2005: 55).

Hadis tersebut memberikan makna bahwa Rasulullah sangat bijak sekali dalam memberikan pembelajaran terhadap umatnya.Meskipun wanita tersebut mengandung dari hasil hubungan zina, beliau tidak memberikan isyarat apapun terhadapnya agar berupaya untuk melakukan aborsi terhadap janin yang dikandungnya. Sebaliknya, Nabi SAW memerintahkan kepada wanita tersebut untuk pulang dan tinggal di rumahnya sampai melahirkan kandungannya. Setelah melahirkan Rasulullah SAW memerintahkan kepadanya agar pulang lagi guna menyusui bayinya sampai masa menyapihnya. Wanita itu pun menyusuinya sampai tiba masa penyapihnya, sedang bayinya itu sudah mulai bisa makan roti. Karena kasih sayang ibu ketika menyusuinya memiliki pengaruh besar dalam pembentukan pribadi anak, yaitu 
ketika dia merasa tenteram dan aman tidak gelisah. Selanjutnya, sebelum melakukan eksekusi hukuman had terhadap wanita tersebut, Nabi SAW terlebih dahulu menyerahkan bayi itu kepada salah seorang di antara kaum muslim untuk memelihara dan mendidiknya. Seperti itulah kisah kasih sayang Nabi SAW pembawa rahmat terhadap anak hasil zina dan keinginannya yang keras agar anak tak berdosa itu tidak tersia-sia hidupnya.

Perkembangan anak (khususnya usia dini) penting dijadikan perhatian khusus bagi orangtua dan guru. Sebab, proses tumbuh kembang anak akan mempengaruhi kehidupan mereka pada masa mendatang. Anak usia dini sendiri merupakan kelompok yang berada dalam proses perkembangan unik, karena proses perkembangannya (tumbuh dan kembang) terjadi bersamaan dengan golden age (masa peka/masa keemasan). Dorothy Law Nolte (1945) menyatakan bahwa:

"Jika anak dibesarkan dengan celaan, ia belajar memaki. Jika anakdibesarkan dengan permusuhan, ia belajar berkelahi. Jika anak dibesarkandengan cemoohan, ia belajar rendah diri. Jika anak dibesarkan denganhinaan, ia belajar menyesali diri. Jika anak dibesarkan dengan toleransi, iabelajar menahan diri. Jika anak dibesarkan dengan dorongan, ia belajarpercaya diri. Jika anak dibesarkan dengan pujian, ia belajar menghargai. Jika anak dibesarkan dengan kasih sayang dan persahabatan, ia belajar menemukan cinta dalam kehidupan."

Berdasar pada pernyataan Nolte tersebut, kasih sayang mempunyai dampak yang luar biasa terhadap karakter dan pola interaksi individu. Kasih merupakan reaksi emosional yang muncul terhadap seseorang, binatang, benda ataupun segala sesuatu yang berada di sekitarnya. Faktor belajar memainkan peran penting untuk menentukan kepada siapa kasih sayang itu ditujukan pada orang atau objek yang khusus. Agar dapat menjadi emosi yang menyenangkan dan dapat menunjang penyesuaian yang baik, kasih sayang yang harus berbalas. Harus ada tali penyambung antara anak-anak dengan orang-orang yang berarti dalam kehidupan mereka. Bossard dan Boll memberi nama pada hubungan yang timbal balik ini sebagai "komplek empati (the empathic complex)"(Cramer dan Hogan, 1975: 145-154). 
Garrison (Hurloc, 1978: 228) menekankan keseimbangan dalam hubungan tersebut.

Cinta merupakan hal yang timbal balik dan tumbuh dengan baik apabila sekaligus diberikan dan juga diterima. Penolakan yang terus menerus di rumah mungkin menyebabkan kemampuan anak untuk memberikan kasih sayang tidak berkembang, atau mungkin menyebabkan dia mencari kasih sayang dari orang lain di luar rumah. Kasih sayang yang berlebihan dan pemanjaan dapat menimbulkan pengaruh yang tidak diinginkan sebagaimana penolakan atau kekurangan kasih sayang. Oleh karena itu, ada bahaya bahwa kasih sayang berlebih-lebihan terhadap satu atau kedua orang tua akan cenderung meniadakan kasih sayang terhadap teman sebaya.

Karena kasih sayang anak-anak terhadap orang lain dipengaruhi oleh jenis hubungan yang ada di antara mereka, sehingga dapat dimengerti bahwa kasih sayang anak-anak kepada masing-masing anggota keluarga berbeda. Anak-anak memperlihatkan kasih sayang yang lebih besar terhadap saudara yang memperlihatkan kasih sayang kepada mereka dan tidak mengkritik, menggoda, menggertak atau yang tidak bersikap acuh tak acuh. Berikut rumus singkat SAYANG (Probo, 2008) yang dapat dijadikan pengingat sederhana untuk pendekatan dalam proses pembelajaran untuk mengembangkan karakter anak:

S-apa-senyum-sentuh-serahkan sesuatu untuknya

A-mbil hatinya (puji dulu, lalu masukkan pesan atau nilai)

Y-akin berhasil dan yakin bermanfaat dan yakin baik sangka

A-mati kondisi fisik dan psikis agar terus berguna

$\mathbf{N}$-iteni (mencermati), nilai agama (sifat luhur budi)

G-erak lagu, gaul.

Dalam penelitiannya, Yehudit Shefi (2015) menyimpulkan pentingnya hubungan yang baik antara pendidik dan peserta didik. Hal ini dapat mencegah terjadinya putus sekolah dan menjadi katalis untuk memotivasi siswa dalam belajar dan bersikap di dalam sekolah. Hal ini mempertegas pentingnya peran pendidik 
dalam memberikan kasih sayang dan nasihat untuk kesuksesan peserta didik.

Hadar dkk (2016) dalam penelitiannya tentang Talk About Student Learning (TASL) menyatakan tiga hal penting untuk menciptakan pembelajaran yang lebih produktif. Tiga hal tersebut adalah pemahaman terhadap peserta didik, nasihat kepada peserta didik, dan pembentukan meta-analisis peserta didik. Tidak hanya hal tersebut, penelitiannya juga menitikberatkan pentingnya hubungan pendidik dan peserta didik dalam proses pembelajaran.

Melalui pendekatan kasih sayang ini maka kedekatan emosional antara pendidik dengan peserta didik akan terjalin, sehingga dengan mudah pendidik dapat memberikan arahan, nasehat, dan bimbingan yang baik kepada peserta didik. Nasehat diberikan berupa penjelasan tentang prinsip yang haq dan bathil. Memberikan nasehat merupakan proses pemasangan parameter ke dalam jiwa anak sehinggaa bisa menjadi paradigma berpikir. Untuk itu, disyaratkan guru harus terlebih dahulu membersihkan diri dari sifat-sifat tercela agar nasihat yang diberikan membekas dalam jiwa anak didik (Syeikh Burhanudin al-Zarnuji, Ta'lim al-Muta'allim Thariq al-Ta'allum: 46). Pemberian nasehat harus dengan kesan yang baik, bijak, dan bahasa yang mudah dimengerti.

\section{Metode Mudzakarah, Munadharah, dan Mutharahah}

Syeikh al-Zarnuji menuliskan bahwa:

$$
\begin{aligned}
& \text { ولا بـد لطالب العلم من المـذاكرة، والمناظرة، والمطارحة، } \\
& \text { فينبغى أن يكون كل منها بالإنصاف والتأنى والتأمل، ويتحرز } \\
& \text { عن الشغب [والغضب]، فإن المناظرة والمـذاكرة مشاورة، } \\
& \text { والمشاورة إنما تكون لاستخراج الصهواب وذلك إنما يحصل } \\
& \text { بالتأمل والتأنى والإنصاف، ولا يحصل بالغضيب والشغب. }
\end{aligned}
$$

Seorang pelajar seharusnya melakukan mudzakarah (forum saling mengingatkan), munadharah (forum saling mengadu pandangan) dan mutharahah (diskusi). Hal ini dilakukan atas 
dasar keinsyafan, kalem dan penghayatan serta menyingkiri halhal yang berakibat negatif. Munadharah dan mudzakarah adalah cara dalam melakukan musyawarah, sedang permusyawaratan itu sendiri dimaksudkan guna mencari kebenaran. Karena itu, harus dilakukan dengan penghayatan, kalem dan penuh keinsyafan. Dan tidak akan berhasil, bila dilaksanakan dengan cara kekerasan dan berlatar belakang yang tidak baik. Syeikh al-Zarnuji memberi rambu-rambu agar ketika mengingatkan siswa tidak melampaui batas karena bisa menyebabkan siswa tidak menerimanya. Oleh sebab itu, al-Zarnuji memberi arahan agar guru harus memiliki sifat lemah lembut, menjaga diri dari sifat pemarah.

Berdasarkan pada penjelasan Syeikh al-Zarnuji, guru harus mampu mengembangkan situasi kelas yang memungkinkan pertukaran ide secara bebas dan terbuka. Dalam pembelajaran di kelas, guru berperan sebagai fasilitator, organisator dan motivator. Hal ini dikarenakan setiap kajian keilmuan yang ada dimungkinkan tidak dapat secara langsung dipahami oleh siswa. Ketika dihadapkan pada suatu permasalahan atau kajian ilmu, pegetahuan sebelumnya diperlukan siswa untuk mengkonstruksi pengetahuan barunya tersebut. Siswa yang mampu menemukan benang merah antara permasalahan tersebut dengan permasalahan sebelumnya, maka siswa akan berusaha menyelidiki terlebih dahulu apa yang menjadi konsep utama yang ada dalam permasalahan tersebut. Berusaha mengidentifikasi permasalahan tersebut, kemudian berusaha untuk melakukan refleksi atas pengetahuan yang telah dimilikinya pada pembelajaran yang sebelumnya. Akan tetapi, untuk siswa yang merasa kesulitan dan sulit untuk mencari pengetahuan yang relevan untuk menyelesaikan permasalahan baru tersebut, mereka cenderung menyerah begitu saja tanpa melakukan usaha penyeledikan terkait kajian ilmu tersebut. Guru dapat melakukan mudzakarah dengan teknik scaffolding.

Teknik scaffolding digunakan untuk membantu siswa secara tidak langsung untuk mengingat materi sebelumnya yang telah dipelari dan mengkonstruksikannya dengan pengetahuan baru yang dipelajari. Teknik scaffolding dapat dilakukan dengan menggunakan teknik bertanya dan teknik probing yang efektif, atau memberikan petunjuk (hint) seperlunya (Herman, 2007: 
54). Bantuan yang diberikan guru kepada siswa ini tergantung kepada pengetahuan siap siswa (prior knowledge) dan guru mempertimbangkan berbagai alternatif solusi masalah yang berada dalam koridor pengetahuan siswa. Melalui pertanyaan yang mengarahkan, maka struktur kognitif siswa akan lebih terorganisir, jelas dan stabil. Menurut Slameto (Rahman, 2011) semakin jelas, stabil serta terorganisasinya struktur kognitif seseorang, maka proses belajar yang bermakna dan retensi akan mudah terjadi pada orang tersebut. Sebaliknya, pada struktur kognitif yang tidak stabil, kabur dan tidak terorganisasi dengan baik cenderung merintangi proses belajar bermakna. Dengan demikian trajectory of understanding siswa dapat terjembatani.

Namun demikian, dalam kegiatan memberikan scaffolding tersebut tidak mudah begitu saja berjalan secara lancar, jika guru maupun siswa tidak memperhatikan dan mempertimbangkan aspek emosional. Guru yang mengesampingkan aspek batin, seperti: mudah melontarkan kalimat yang menyinggung siswa; terlalu menekan siswa; menunjukkan sikap yang kesal; dan tidak peduli terhadap kesulitan siswa; akan menghambat siswa menjadi pembelajar maupun pemecah masalah yang handal (Shapiro, 2003: 143). Menurut Shapiro (2003: 148-149) perilaku guru yang mengesampingkan aspek kecerdasan emosional itu dapat membuat suasana yang tidak mendukung kegiatan memecahkan masalah dan tidak membantu perkembangan kecerdasan emosional siswa. Dengan demikian kecerdasan emosional perlu diperhatikan, baik pada diri guru maupun siswa. Demikian halnya dengan siswa yang tidak mampu mengolah rasa dan emosinya untuk me-recall pengetahuan yang diperoleh sebelumnya maka siswa akan cenderung malas dan putus asa. Dengan demikian, antara guru dan siswa dalam upaya mudzakarah ini diperlukan kontrol emosi yang baik sehingga melalui kegiatan scaffolding ini terbentuk karakter yang siswa yang sabar, jujur, kerja keras dan sungguh-sungguh, mandiri, disiplin, tanggung jawab, menghormati guru, dll.

Selanjutnya, Syeikh al-Zarnuji tersebut juga berpesan agar dalam pembelajaran terdapat proses diskusi dan bertukar pandangan. Dalam hal ini Syeikh al-Zarnuji menggunakan 
istilah munadharah, dan mutharahah. Munadharah dan mudzakarah adalah cara dalam melakukan musyawarah, sedang permusyawaratan itu sendiri dimaksudkan guna mencari kebenaran. Karena itu, harus dilakukan dengan penghayatan, kalem dan penuh keinsyafan. Sebagaimana Syeikh al-Zarnuji juga menjelaskan terkait musyawarah sebagai berikut:

$$
\begin{aligned}
& \text { وفائدة المطارحة والمناظرة أقوى من فائدة مجرد التكرار لأن } \\
& \text { فياء تكرارا وزيـادة. وقيل: مطارحة ساعة، خير من تكرارشهر. } \\
& \text { لكن إذا كان [مع] منصف سليم الطبيعة. وإياك والمذاكرة مع } \\
& \text { متعنت غير مستقيم الطبع، فإن الطبيعة متسرية، والأخلاق } \\
& \text { متعدية، والمجاورة مؤثرة. }
\end{aligned}
$$

Faedah mutharahah dan mudzakarah itu jelas lebih besar daripada sekedar mengulang pelajaran sendirian, sebab disamping mengulang pelajaran, juga menambah pengetahuan yang baru. Ada sebuah perkatakan: "Sesaat mutharahah dilakukan, lebih bagus mengulang pelajaran sebulan. "Sudah tentu harus dilakukan dengan orang yang insaf dan bertabiat jujur. Awas jangan mudzakarah dengan orang yang sekedar mencari menang dalam pembicaraan semata, lagi pula bertabiat tidak jujur. Sebab tabiat itu suka merampas, akhlak mudah menjalar sedang perkumpulan pengaruhnya besar.

Berdasar pada Kitab Ta'lim al Muta'allim tersebut, tidak hanya sekedar interaksi antara siswa dengan materi atau sumber/ bahan ajar, interaksi antara siswa dengan guru, akan tetapi, syaikh al-Zarnuji juga menjelaskan perlunya interaksi antara siswa dengan siswa lainnya, yaitu melalui musyawarah atau diskusi. Dalam kelompok diskusi tersebut, hanya sebagian kecil siswa yang mendominasi dan aktif, sedangkan sebagian besar siswa yang lain pasif. Sehingga ketika dihadapkan pada permasalahan yang berbeda dari apa yang dicontohkan guru, siswa cenderung tidak mampu untuk mencari penyelesaian atau pemecahan masalah dengan menghubungkan hal-hal yang menjadi pokok permasalahan tersebut dengan struktur kognitif relevan yang 
telah dimilikinya. Hal ini sesuai dengan apa yang dirumuskan Lev Vygotsky.

Seperti halnya Piaget, Vygotsky percaya bahwa perkembangan intelektual terjadi pada saat individu berhadapan dengan pengalaman baru yang menantang dan ketika mereka berusaha untuk memecahkan masalah yang dimunculkan oleh pengalaman ini (Arends, 2008: 46). Vygotsky juga percaya bahwasannya, interaksi sosial dengan teman lain akan memacu terbentuknya ide baru dan memperkaya perkembangan intelektual siswa (Ibrahim dan Nur, 2000: 18). Ketika para siswa mengembangkan metode atau cara untuk mengkonstruksi prosedur mereka sendiri, mereka sedang memadukan pengetahuan konseptual mereka dengan keterampilan prosedural mereka.

Menurut Vygotsky fungsi mental yang lebih tinggi pada umumnya muncul dalam percakapan atau kerjasama antar individu sebelum fungsi mental yang lebih tinggi itu terserap ke dalam individu tersebut (Arends, 2008: 47). Sehingga pembelajaran dapat terjadi melaui interaksi sosial dengan guru dan teman sejawat. Melalui tantangan dan bantuan dari guru atau teman sejawat, siswa akan bergerak ke dalam zona perkembangan terdekat mereka dimana pembelajaran yang baru terjadi. Dalam hal ini, guru dituntut untuk memfasilitasi siswa untuk mengembangkan kemampuan yang ada dalam dirinya.

Pada saat diskusi sebaiknya guru memberikan motivasi siswa untuk mengembangkan keilmuannya dan keterampilannya dalam bertukar pendapat. Guru sebagai fasilitator sebaiknya hanya perlu mengkondisikan agar siswabekerja dengan pengetahuan awal dan keyakinan mereka sendiri. Dengan katalain, hindari campur tangan guru yang terlalu banyak. Seperti halnya diungkapkan Shapiro (2003) bahwa penilaian guru yangterlalu rendah terhadap kemampuan siswa dalam memecahkan masalah dapatmengakibatkan mereka menjadi kurang percaya diri dalam memecahkanmasalah. Guru harus dapat menahan diri untuk memberikanbantuan, sehingga mereka tetap berjuang menyelesaikan masalah yangdiberikan. Hal ini berarti siswa dilatih karakter untuk mandiri, gemar membaca, jujur, dan disiplin. Ungkapan guru berkenaan dengan membolehkannya 
siswa untuk melakukan kesalahan, sangat penting. Karena hal ini akan membuat mereka terlepas dari cemas yang berlebihan (Shapiro, 2003: 166-169). Sementara itu, di sisi lain Boaler \& Humphies (Walle, 2007: 46) menyatakan bahwa kesalahan yang dibuat oleh siswa akan menguntungkan dan memperkaya dalam diskusi. Dengan kata lain, guru harus menerima siswa secara positif ketika ada siswayang merespon masalah yang diberikan guru jauh dari yang seharusnya. Dan sebaiknya berawal dari respon siswa itulah, guru bisa mengarahkannya pada pengetahuan yang diharapkan dapat dibentuk siswa. Dengan demikian, melalui diskusi ini siswa akan menyadari pentingnya toleransi, menghargai pendapat, bersahabat/komunikatif, cinta damai, dan tanggung jawab selama proses diskusi berlangsung sehingga mampu mentransformasikannya dalam kehidupan nyata sehari-hari.

\section{Metode Pembentukan Mental Jiwa}

Dalam metode ini ditekankan beberapa aspek yaitu: niat, menjaga sifat wara', istifadah (mengambil faedah guru), dan tawakkal. Syeikh al-Zarnuji menjelaskan, sukses dan gagalnya pendidikan Islam tergantung dari benar dan salahnya dalam niat belajar. Niat yang benar yaitu niat yang ditujukan untuk mencari ridha Allah subhanahu wa taala, memperolah kebahagiaan (sa'adah) di dunia akhirat, memerangi kebodohan yang menempel pada diri dan melestarikan ajaran Islam. Harus ditekankan kepada anak didik bahwa belajar itu bukan untuk mendapatkan popularitas, kekayaan atau kedudukan tertentu, tapi mendapatkan ridha Allah. Selama dalam proses belajar, anak didik harus dibiasakan bersifat wara' (menjaga dari). Syeikh al-Zarnuji mengatakan, "hanya dengan wara' ilmu akan berguna" (hal. 9). Sebagaimana Syaikh al-Zarnuji menjelaskannya dalam Fasal XI sebagai berikut:

$$
\begin{aligned}
& \text { روى بعضهم حديثا فى هذا الباب عن رسول الله صلى الله عليه } \\
& \text { وسـلم أنـا قـال: من لم يتورع فى تعلماه ابتلاه الله تعالى بأحد }
\end{aligned}
$$

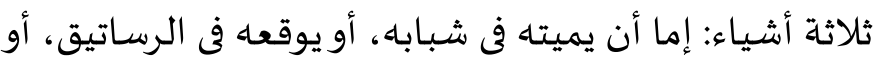




$$
\text { يبتليـه بخـدمة السلطان؛ فكلما كان طالب العلم أورع كان علمها والتعلم لله أيسروفوائده أكثر. }
$$

Dalam masalah wara', sebagian ulama meriwayatkan hadist dari Rasulullah SAW: "Barang siapa tidak berbuat wara' waktu belajarnya, maka Allah memberinya ujian dengan salah satu tiga perkara: dimatikan masih berusia muda, ditempatkan pada perkampungan orang-orang bodoh atau dijadikan pengabdi sang pejabat”. Jikalau mau membuat wara' maka ilmunya lebih bermanfaat, belajarpun mudah dengan banyak-banyak berfaedah.

Sikap wara' adalah menjaga diri dari perbuatan maksiat, menjaga perut dari makanan haram dan tidak berlebihan memakan makanan, tidak berlebihan dalam tidur, serta sedikit bicara. Suatu hikayat, dicritakan bahwa syaikhul Jalil Muhammad Ibnul Fadl di waktu masa belajarnya, tidak pernah makan makanan pasar. Ayahnya sendiri seorang dusun yang selalu mengiriminya setiap hari Jumat. Pada suatu hari, sang ayah mengetahui ada roti pasar di kamar Muhammad. Ayahnya pun marah, dan tidak mau berbicara dengan sang putra. Muhammad matur dan katanya: saya tidak membeli roti itu dan memang tidak mau memakannya, tetapi itu pemberian temanku, ayah. Jawabnya: bila kau berhati-hati dan wara' niscaya temanmu takkan sembarangan memberikan roti seperti itu. Demikianlah pelajar-pelajar zaman dulu berbuat wara' dan ternyata banyak-banyak bisa memperoleh ilmu dan mengajarkannya, hingga keharuman nama mereka tetap abadi sampai kiamat.

Metode istifadah adalah guru menyampaikan ilmu dan hikmah, menjelaskan perbedaan antara yang haq dan batil dengan penyampaian yang baik sehingga murid dapat menyerap faidah yang disampaikan guru. Seorang murid dianjurkan untuk mencatat sesuatu yang lebih baik selama ia mendengarkan faidah dari guru sampai ia mendapatkan keutamaan dari guru.

Nilai batiniyah berikutnya adalah tawakkal dalam mencari ilmu. Guru harus menanam secara kuat dalam jiwa murid untuk bersikap tawakal selama mencari ilmu dan tidak sibuk dalam mendapatkan duniawai. Sebab, menurut al-Zarnuji, kesibukan lebih dalam mendapatkan duniawi dapat menjadi halangan untuk 
berakhlak mulia serta merusakkan hati. Sebaliknya, baik guru maupun murid harus menyibukkan dengan urusan ukhrawi. Sebab pada hakikatnya kehidupan itu adalah dari Allah dan untuk Allah, maka seorang siswa itu harus siap dengan segala konsekuensi kehidupan.

Syaikh al-Zarnuji menjelaskan ada tiga hal yang mengharuskan para pembelajar untuk tawakkal, yaitu pertama rizki, pelajar harus bertawakal dalam menuntut ilmu. Jangan goncang karena masalah rizki, dan hatinya pun jangan terbawa dalam masalah tersebut. Imam Abu Hanifah meriwayatkan dari Abdullah Ibnul Hasan Az-Zubaidiy sahabat Rasulullah SAW: "Barangsiapa mempelajari agama Allah, maka Allah akan mencukupi kebutuhannya dan memberinya rizki dari jalan yang tidak dikira sebelumnya." Orang yang hatinya terpengaruh urusan rizki baik makanan atau pakaian, maka jarang sekali yang dapat menghapus pengaruh tersebut untuk mencapai budi luhur dan perkara-perkara yang mulia. Kedua, pengaruh urusan dunia. Bagi yang mengunakan akal, hendaknya jangan tergelisahkan oleh urusan dunia, karena merasa gelisah dan sedih di sini tidak akan bisa mengelakan musibah, bergunapun tidak. Malahan akan membahayakan hati, akal dan badan serta dapat merusakan perbuatan-perbuatan yang baik. Tapi yang harus diperhatikan adalah urusan-urusan akhirat, sebab hanya urusan inilah yang akan membawa manfaat. Ketiga, hidup dengan prihatin. Dijelaskan dalam kitab Ta'lim al Muta'allim bahwa siapa yang bersabar dalam menghadapi segala kesulitan di atas, maka akan mendapat kelezatan ilmu yang melibihi segala kelezatan yang ada di dunia. Hal ini terbukti dengan ucapan Muhammad Ibnul Hasan setelah tidak tidur bermalam-malam lalu terpecahkan segala kesulitan yang dihadapinya, sebagai berikut: "dimanakah letak kelezatan putra-putra raja, bila dibandingkan dengan kelezatan yang saya alami kali ini."

Keempat, menggunakan seluruh waktu untuk ilmu. Syaikh al-Zarnuji menjelaskan bahwa hendaknya pelajar tidak terlena dengan segala apapun selain ilmu pengetahuan, dan tidak berpaling dari fikih. Muhammad berkata: "Sesungguhnya perbuatan seperti ini, adalah dilakukan sejak masih di buaian hingga masuk liang 
kubur. Barangsiapa meninggalkan ilmu kami ini sesaat saja, akan habislah zaman hidupnya." Hal ini berarti bahwa menuntut ilmu tidak memandang waktu (thuli zaman)

$$
\text { أطلب العلم من المهد الى اللهد }
$$

Carilah ilmu sejak dari ayunan hingga liang lahat.

Hal ini menunjukkan bahwa belajar tidak mengenal ruang waktu. Belajar tidak hanya dapat dilakukan di ruang kelas saat jam pelajaran. Akan tetapi, belajar dapat dilakukan dimanapun, dan kapanpun. Lebak (2006:385) menyatakan, The Classroom is a limited environment. The school science program must extend beyond the walls of the school to the resources of the community. Pernyataan ini menunjukkan bahwa ruang kelas bukanlah satusatunya tempat untuk memperoleh ilmu. Ilmu dapat diperoleh dimanapun, kapanpun, dan dari siapapun. Tidak ada shortcut dalam proses belajar. Segalanya memerlukan proses yang tidak instan. Pendidikan seumur hidup yang kadang dikenal dengan istilah life long education memungkinkan seseorang untuk mengembangkan potensi-potensinya. Hal ini tidak hanya peran siswa untuk melakukan hal ini, akan tetapi juga guru berperan dalam melaksanakan hal ini. Manusia adalah makhluk hidup yang diciptakan dengan akal. Hal inilah yang membedakan manusia dengan makhluk lainnya. Prof. Utoro Yahya mengatakan bahwa "human is a thinking animal". Manusia adalah hewan yang berpikir. Sehingga, saat manusia berhenti untuk berpikir, maka yang tertinggal hanya hewannya.

Berpikir dan menuntut ilmu adalah perintah agama yang wajib dilaksanakan. Di dalam Alquran, kata al-ilm dan katakata jadiannya digunakan lebih dari 780 kali (Ghulayani, 1995: 39). Dalam berpikir, juga tidak mengenal waktu, baik siang ataupun malam. "dan di waktu malam. Maka apakah kamu tidak memikirkan?” (QS. Ash Shaffaat, 37: 138) “(yaitu) orang-orang yang mengingat Allah sambil berdiri atau duduk atau dalam keadan berbaring dan mereka memikirkan tentang penciptaan langit dan bumi (seraya berkata): "Ya Tuhan kami, tiadalah Engkau menciptakan ini dengan sia-sia, Maha Suci Engkau, maka peliharalah kami dari siksa neraka." (QS. Ali Imran, 3: 191). Inti 
dari pembelajaran seumur hidup adalah bahwa seluruh manusia harus memiliki kesempatan yang sistematik, terorganisir untuk belajar di setiap kesempatan hidup mereka. Semua itu bertujuan untuk memperbaharui kemampuan dan untuk meningkatkan keahlian mereka dalam rangka beradaptasi serta memperoleh skill baru. Hal ini diperkuat dengan pernyataan Jerome Bruner. "Pendidikan bukan sekedar persoalan teknik dan pengolahan informasi, bahkan bukan penerapan "teori belajar" di kelas atau menggunakan hasil "ujian prestasi" yang berpusat pada mata pelajaran. Pendidikan merupakan usaha yang kompleks untuk menyesuaikan kebudayaan dengan kebutuhan anggotanya, dan menyesuaikan anggotanya dengan cara mereka mengetahui kebutuhan kebudayaan." (Baharuddin, 2007: page cover)

\section{Simpulan}

Kitab Ta'lim al-Muta'allim merumuskan tiga metode penting dalam pembentukan karakter yang mencakup adab dhahir dan batin. Adapun metode tersebut meliputi metode ilqa' al-nasihah (pemberian nasehat) dan kasih sayang; metode Mudzakarah, Munadharah, dan Mutharahah; Metode pembentukan mental jiwa. Ketiga metode tersebut masih layak dan relevan dengan dunia pendidikan modern. Hal tersebut menunjukkan bahwa teori tersebut masih dapat digunakan dan diterapkan dalam dunia pendidikan modern untuk membentuk karakter peserta didik yang mulia. 


\section{DAFTAR PUSTAKA}

Baharuddin dan Wahyuni, E. N. 2007. Teori Belajar dan Pembelajaran. Jogjakarta: Ar Ruzz Media.

Cramer, P., \& K. A. Hogan. 1975. Sex Differences in Verbal and Play Fantasy: Development Psychology, 145-154.

Elizabeth B. Hurloc. 1978. Child Development, London: McGrawHill, Inc.

Gulayani, M. 1995. Filsafat Sains menurut Al-Quran. Bandung: Mizan.

Hadar, L. L., \& Brody, D. L. 2016. Talk about student learning: Promoting professional growth among teacher educators. Teaching and Teacher Education, 59, 101-114.

Hadi, S. 1989. Metodologi Research. Yogyakarta: Andi Offset.

Ibrahim, M \& Nur, M. 2000. Pembelajaran Berdasarkan Masalah. Surabaya: UNESA Press

Jalaluddin dan Idi, A. 2010. Filsafat Pendidikan. Jogjakarta: Arruzz Media

Lebak, K,. 2006. Using Field Trip Experiences to Further the Participation in and Learning of Science, dalam Teaching and Learning Science Journal, 45. 385.

Rahman, J. A. 2005. Tahapan Mendidik Anak Teladan Rasulullah. Bandung: Irsad Baitus Salam.

Rahman, T. 2011. Peranan Pertanyaan Terhadap Kekuatan Retensi dalam Pembelajaran Sains pada Siswa SMU. EDUCARE: Jurnal Pendidikan dan Budaya

Roh, K. H. 2003. Problem-based Learning in Mathematics. Clearinghouse for Science, Mathematics, and Environmental Education. [Online]. Available: http:// www.vtaide.com/png/ERIC/PBL-in-Math.htm September 2010].

Salahudin dan Alkrienciehie. 2013. Pendidikan Karakter Pendidikan Berbasis Agama dan Budaya Bangsa. Bandung: Pustaka Setia. 
Salahudin, A. dan Alkrienciehie, I. 2013. Pendidikan Karakter Pendidikan Berbasis Agama dan Budaya Bangsa. Bandung: Pustaka Setia.

Shapiro, E. L. 2003. Mengajarkan Emotional Intelligence pada Anak. Jakarta: Gramedia.

Shefi, Y. 2015. The Contribution of Teacher-Student Relationships to Perseverance, Dropout Prevention and Motivation for Change in Students' Attitudes in "Second Chance" High School. Procedia-Social and Behavioral Sciences, 209, 470475.

Walle, V. A. J. 2005. Elementary and Middle School Mathematics. Singapore: Pearson Education

Wena, M. 2011. Strategi Pembelajaran Inovatif Kontemporer. Jakarta: PT Bumi Aksara.

Zainuddin, dkk,. 2009. Pendidikan Islam dari Paradigma Klasik Hingga Kontemporer. Malang: UIN Malang Press. 